Resumen por la autora, C. J. Beckwith.

Colegio Vassar, Poughkeepsie, N. Y.

Nota sobre una vejiga pancreática anómala en el gato.

En una disección de un gato se encontró una vejiga pancreática. Su conducto se abría en el conducto pancreático principal. El ejemplar descrito difiere de otros casos en la presencia de una rama comunicante entre el conducto de la vejiga pancreática y el conducto cístico, cerrado por encima de este nuevo conducto comunicante. Esta particularidad aisla la vejiga biliar del conducto cístico, transformando a este último en un órgano no funcional. La vejiga pancreática aparentemente asume la función de la vejiga biliar, pasando a ella la bilis desde el conducto cístico a lo largo de la rama comunicante.

Translation by José $\mathbf{F}$. Nonidez

Carnegie Institution of Washington 


\title{
NOTE ON A PECULIAR PANCREATIC BLADDER IN THE CAT
}

\author{
CORA JIPSON BECKWITH \\ Vassar College \\ TWO FIGURES
}

The presence of a pancreatic bladder lying in the liver beside the gall-bladder has been reported in a few cases in the cat. The case here presented differs from these sufficiently to make a note of it desirable. A brief review of the condition in those forms which I have found recorded will be necessary for comparison. These all belong to one general type with slight modification of the ducts.

Mayer, in 1815, describes the appearance of a pancreatic bladder lying on the right side of the gall-bladder. Its duct which lay parallel to the ductus choledochus (common bile-duct) opened into the duct of Wirsung or main pancreatic duct just before it entered the duodenum. The pancreatic bladder is smaller than the gall-bladder.

In 1879, Gage records a similar case in which the pancreatic bladder lies at the right side of the gall-bladder and is larger than the latter. The two bladders are very closely bound together by connective tissue, but there is no communication between the two. The duct from the pancreatic bladder leads to the pancreatic duct, into which it opens by two ducts of unequal size, a small one into the duct of Wirsung (main pancreatic duct) and a large one into the gastrosplenic branch of the duct.

No further case was recorded until 1904, when Miller describes three cases in cats which were obtained from the same farm house or a neighboring one. Two of his cases are similar. The gall-bladder occupies its normal position, while the pancreatic bladder which is smaller is bound to the free surface of the gallbladder. In the third case the pancreatic bladder which is 


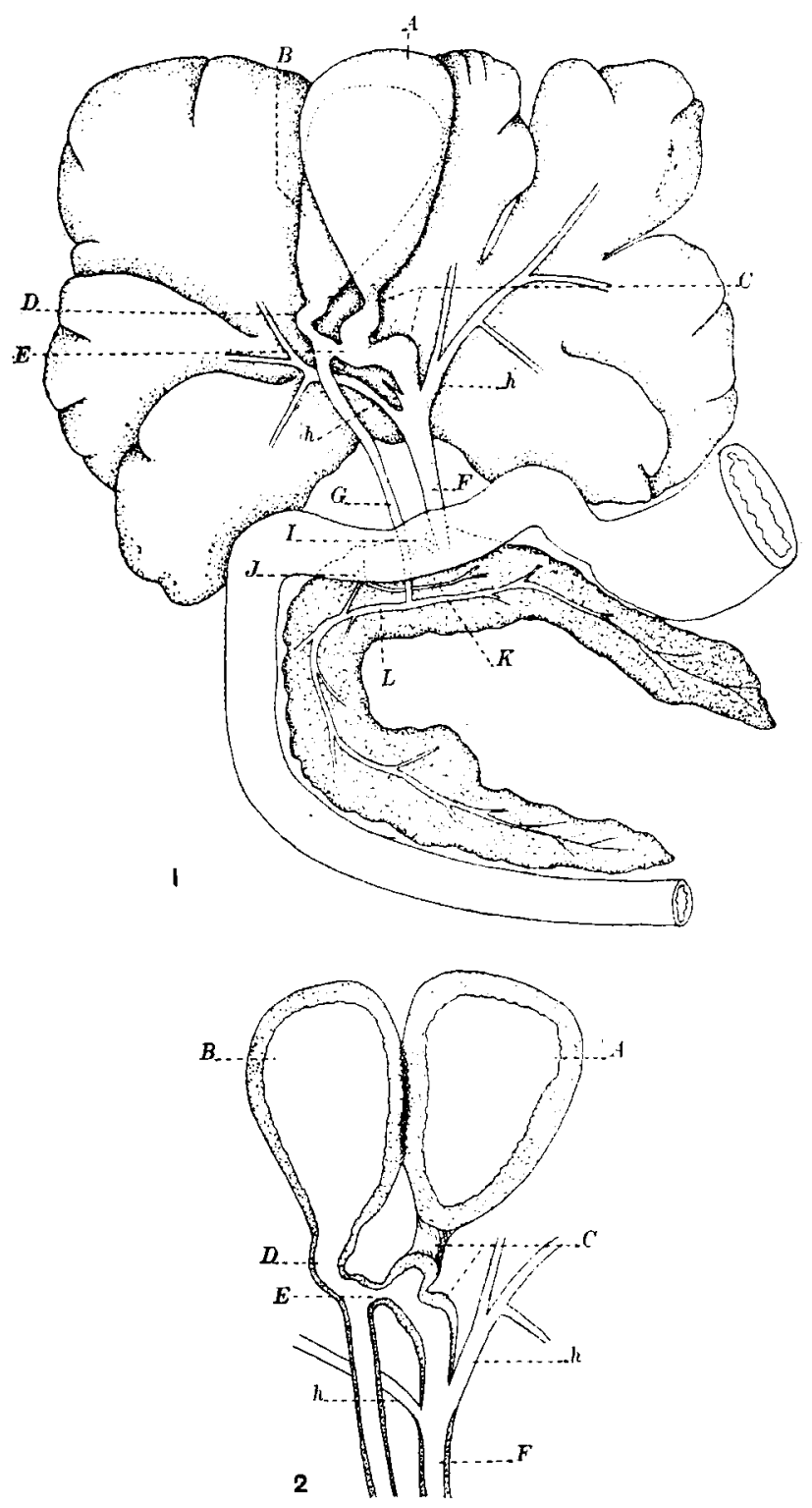


larger occupied the position of the gall-bladder, the latter lying on the right side of the pancreatic bladder, the two being bound together by connective tissue. In all three cases the duct from the pancreatic bladder opened into the duodorsal division of the pancreatic duct- a point in which they differ from the preceding cases.

The case which has come under my observation is that of a preserved cat dissected by a student in the Vassar College laboratory. Its origin is not known. It differs in a number of points from the above cases. The pancreatic bladder, which is smaller than the gall-bladder, lies behind it, partially covered by it (fig. 1). They are bound together along the apposing sides by connective tissue. The duct from the pancreatic bladder lies parallel to the ductus choledochus (common bile-duct) and opens into the duct of Wirsung after the union of the two divisions (duodorsal and gastrosplenic) of the pancreatic duct. The striking thing about this case is a cross-connecting branch between the duct from the pancreatic bladder and the cystic duct. It lies less than a centimeter from the origin of the ducts from their respective bladders. The cystic duct is swollen above and below the point of union with this cross duct, while it is constricted between this bulged portion and the gall-bladder. Dissection of the ducts revealed the fact that the lumen of the duct from the gall-bladder (cystic duct) at the point of constriction, i.e., between the gall-bladder and the communicating branch was closed by connective tissue (fig. 2). The mucous

Fig. 1. Ventral view of the liver and bladders. $A$, gall-bladder; $B$, pancreatic bladder; $C$, cystic duct (closed above communicating branch); $D$, duct from pancreatic bladder; $E$, connecting branch between the cystic duct and the duct from the pancreatic bladder; $F$, ductus communis choledochus (common bile-duct); $G$, duct from pancreatic bladder just before opening in to the pancreatic duct; $h$, ductus hepatici (hepatic ducts); $I$, duct of Wirsung-ductus pancreaticus (main pancreatic duct); $J$, duct of Santorini (accessory pancreatic duct); $K$, gastrosplenic branch of the pancreatic duct; $L$, duodorsal branch of the pancreatic duct.

Fig. 2. Diagram to show the cavities of the bladders and the lumen of the ducts. Lettering as in figure 1. 
lining of the gall-bladder was not continued into this portion. The lining of the cystic duct was slightly thickened in the swollen portions and became continuous with the lining of the duct from the pancreas through the cross connection. This necessitates the flow of bile for storage from the cystic duct through the cross connection into the pancreatic bladder. The flow of bile from the pancreatic bladder to the duodenum has two paths open to it-one through the upper end of the duct from the pancreatic bladder through the cross branch, thence through the cystic duct and common bile duct; the other through the duct from the pancreatic bladder directly to the duct of Wirsung (main pancreatic duct) into the duodenum.

Careful investigation revealed no communication between the two bladders. Unfortunately, both bladders had been opened before I saw the specimen. The student reported the presence of a brownish fluid in both bladders. This means little, since the cat had been preserved in an alcohol-formalin-glycerin mixture for several months. A striking thing is that the mucous lining of the gall-bladder is much thicker than the lining of the functioning pancreatic bladder. So far as sections reveal the structure, there is no essential difference in the mucous lining of the two bladders.

Two possibilities suggest themselves as to the origin of this condition. Miller and Heuer suggest that the pancreatic bladder may have arisen out of a condition described by both of them. They each cite two cats in which an accessory lobe of pancreatic tissue follows the ductus choledochus (common bile-duct) to the gall-bladder. In one of the cases described by Miller the pancreatic tissue extends nearly to the gall-bladder. It contains a duct which joined the duodorsal division of the pancreatic duct. In the second specimen a duct arising from the duodorsal branch of the pancreatic duct and which was bare of pancreatic tissue ran parallel to the ductus choledochus and ended in a lobe of pancreatic tissue which lay in the fossa of the gall-bladder. Heuer's cats correspond in general to Miller's first case, except that the duct present in the accessory lobe of pancreatic tissue joined the gastrosplenic branch of the pancreatic duct. Both 
writers suggest the origin of a pancreatic bladder and duct by the loss of the pancreatic tissue in this lobe, leaving the duct lying parallel to the ductus choledochus, while the free end expands into a bladder. In the ease which I have described a new connection between the duct from the pancreatic bladder and the cystic duct would have, then, to be formed as a new development. The large size of the gall-bladder and its thick walls together with the swollen condition of the duct suggest that such a communication was formed after the blockage of the cystic duct near its origin from the gall-bladder.

The other alternative which occurs to one is based on another condition described by Miller in a cat that was a brother to one of the pancreatic-bladder cases already described. In this form there were two gall-bladders present, one occupied the usual position, the two hepatic ducts from the left lobes of the liver joined its cystic duct. Beyond this point a duct from the right lobes joined the cystic duct to form the common bile-duct. The duct from the median right lobe beyond the point where it branched from that of the right lateral lobe expanded to form the second, smaller gall-bladder lying at the right of the typical gall-bladder. If a duct from an accessory pancreatic lobe such as Miller described joined the duct of this secondary gall-bladder, the condition which I have described and figured would be formed. This supposition seems less favorable to the writer than the one first described, since this one does not account for the blockage of the original cystic duct or the swollen condition of that duct below the stoppage. At most, these suggestions are guesses, accurate knowledge of the origin of such a condition can only rest on the embryology of the pancreas and liver.

\section{BIBLIOGRAPHY}

GAGE, S. H. 1878 The ampulla of Vater and the pancreatic ducts in the domestic cat. Am. Quat. Mic. Jour., vol. 1.

Heder, G. J. 1906 Johns Hopkins Hospital Bull., vol. 17.

Mayer, A. C. 1815 Blase für den Saft des Pancreas. Deutsches Arch. f. Physiol., Bd. 1.

Miller, W. S. 1904 Three cases of a pancreatic bladder occuring in the domestic eat. Am. Jour. Anat., vol. 3. 